\title{
The socio-demographic profile of the acceptor of copper intrauterine device after medical termination of pregnancy in a tertiary care centre
}

\author{
Paresh Shyam$^{1}$, Mili Ronghangpi ${ }^{2 *}$, Ram Chandra Rongphar ${ }^{1}$
}

\begin{abstract}
${ }^{1}$ Department of Obstetrics and Gynecology, Silchar Medical College, Assam, India
${ }^{2}$ Department of Community Medicine, Silchar Medical College, Assam, India
\end{abstract}

Received: 28 September 2019

Accepted: 05 October 2019

\author{
*Correspondence: \\ Dr. Mili Ronghangpi, \\ E-mail: ramili16675@gmail.com
}

Copyright: (C) the author(s), publisher and licensee Medip Academy. This is an open-access article distributed under the terms of the Creative Commons Attribution Non-Commercial License, which permits unrestricted non-commercial use, distribution, and reproduction in any medium, provided the original work is properly cited.

\begin{abstract}
Background: India is going to be highest populous country within less than a decade. To stabilize population growth as well as to reduce maternal mortality and morbidity resulting from unwanted pregnancy, greater utilization of the spacing methods is essential. In spite of several decades of effort the popularity of $\mathrm{Cu}$-T among the Indian woman is not high. Aim of the study was to find out the profile of the $\mathrm{Cu}-\mathrm{T}$ acceptor after medical termination of pregnancy (MTP).

Methods: It was a retrospective study. Socio-demographic data of the woman accepting Cu-IUCD after MTP was collected from family planning operation theatre record book.

Results: The majority of the participants were from rural area. The mean age of the acceptor was 27.28 \pm 4.78 . The maximum number of woman was para two 74 (44.3\%). The number of woman with LCB 2 years or less than 2 years was $96(57.5 \%)$ and that of woman with LCB more than two years was $71(42.5 \%)$.

Conclusions: A significant number of woman use $\mathrm{Cu}$-T after a long gap of two years after last child birth. Woman found to be inclined to use $\mathrm{Cu}-\mathrm{T}$ after having at least one male child.
\end{abstract}

Keywords: Birth spacing, Copper-T acceptor, Family planning, Gender preference, Medical termination of

\section{INTRODUCTION}

India will be highest populous country in the world after 2024. Around 2024, the population of India is expected to surpass that of China. ${ }^{1}$ This huge burden of population is a big obstacle for all round development of the country. Reversible method of contraceptive practice by the eligible couple plays a vital role in the controlling the population explosion. Spacing is one of the key strategies in the family planning component of the $\mathrm{RMNCH}+\mathrm{A} .^{2}$ World health organization (WHO) recommended interval before attempting the next pregnancy is at least 24 months after a live birth in order to reduce the risk of adverse maternal, perinatal and infant outcomes. ${ }^{3}$ Long acting reversible contraceptive (LARC) are very effective method for spacing childbirth. Intra uterine contraceptive device (IUCD) is a suitable LARC method for Indian woman. Insertion of an IUD immediately after abortion is safe and practical. ${ }^{4}$ It is free from hormonal side effect, does not disturb regular cyclical menstruation. Though $\mathrm{Cu}-\mathrm{T}$, an intrauterine contraceptive device (IUCD), is freely provided by Government of India for last few decades the acceptance is very low. $\mathrm{Cu}-\mathrm{T}$ must be popularized among the Indian woman for spacing of childbirth and to reduce unwanted pregnancy. In addition, adoption of effective method of contraception will lead to 
reduction of abortion related mortality and morbidity. To know about the socio-demographic pattern of the IUCD acceptor is essential to increase the acceptance of $\mathrm{Cu}-\mathrm{T}$ among eligible couple. Analysis of the factor influencing the acceptance of $\mathrm{Cu}$ - $\mathrm{T}$ will help to deal with the relevant factors by adopting proper family planning programme. Insertion of an IUD immediately after abortion is safe and practical. ${ }^{4}$

In this backdrop it is very pertinent to document the profile of the women who accepted $\mathrm{Cu}-\mathrm{T}$. The present study was conducted to find out the profile of the $\mathrm{Cu}-\mathrm{T}$ acceptor after undergoing medical termination of pregnancy (MTP).

\section{METHODS}

The study was conducted in woman who accepted $\mathrm{Cu}-\mathrm{T}$ after MTP in the Department of Obstetrics and Gynaecology, Silchar Medical College, Silchar, Assam. The period of study was from June 2017 to July 2018. It was a retrospective descriptive study.

\section{Inclusion criteria}

- All cases who accepted Cu-T after MTP by suction evacuation.

\section{Exclusion criteria}

- $\mathrm{Cu}-\mathrm{T}$ inserted after delivery (PPIUCD) were excluded.

The data were collected from records of family planning operation theatre record book.

\section{Statistical analysis}

Data were entered into MS excel. Statistical analysis was performed by "MS Excel" and "Soscistatistics". Categorical data were presented as frequencies and continuous data as mean \pm standard deviation (SD).

\section{RESULTS}

The total number of $\mathrm{Cu}-\mathrm{T}$ inserted after MTP was 167 during the study period.

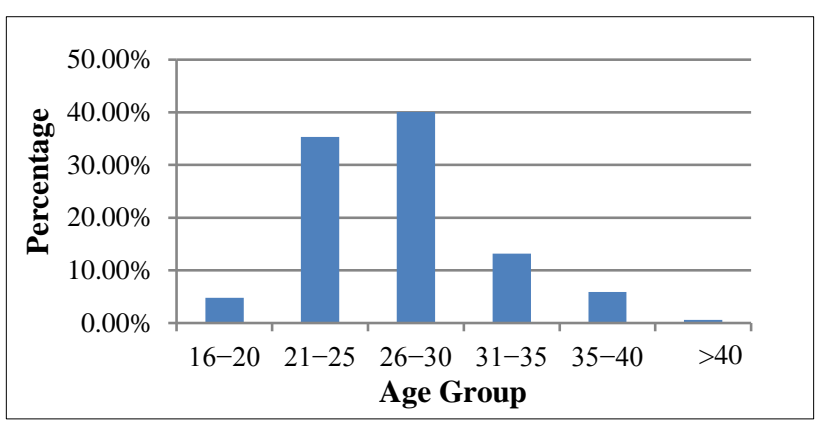

Figure 1: Age group.
The number of acceptors in the age group 21-25 years and 26-30 years age group together was highest 126 (75.4\%). The mean age was $27.28 \pm 4.78$.

The maximum number of woman was para two 74 (44.3\%). The number of primipara was 50 (29.9\%). Most of the acceptor were para two or less 124 (74.2\%).

Table 1: Place of residence.

\begin{tabular}{|lll|}
\hline Residence & Number & Percentage \\
\hline Rural & 139 & $16.8 \%$ \\
\hline Urban & 28 & $83.2 \%$ \\
\hline
\end{tabular}

The residence of the most of the acceptor was rural 139 $(83.2 \%)$.

Table 2: Last child birth.

\begin{tabular}{|lll|}
\hline Last child birth & Number & Percentage \\
\hline$<1-1$ Year & 42 & $25.2 \%$ \\
\hline$>1-2$ Year & 54 & $32.3 \%$ \\
\hline$>2-3$ Year & 18 & $10.8 \%$ \\
\hline$>3$ Year & 53 & $31.7 \%$ \\
\hline
\end{tabular}

The number of woman with last child birth (LCB) two years or less than two years was $96(57.5 \%)$ and that of with more than two years was $71(42.5 \%)$. The total number of living children of the acceptor was 347 . The number of male child and female child was 282 and 165 respectively.

\section{DISCUSSION}

The mean age of $\mathrm{Cu}-\mathrm{T}$ acceptor was $27.28 \pm 4.78$. The highest number of patients $126(75.4 \%)$ belongs to age group 21 years to 30 years. Similar finding were reported by Biswas R and Chandra S, Samel DR..$^{5-7}$ The number of woman beyond 30 years of age is less. Most of the women might have the desired number of children (completed her family) by 30 years of age and they opt for permanent method of contraception. The number of woman in the age group less than 21 years is very less (5\%) in the present study. This might be because marriage and pregnancy before 21 years of age are uncommon.

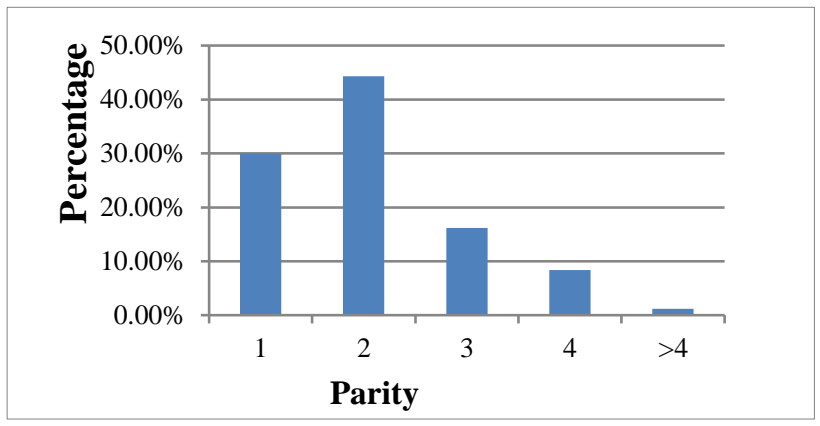

Figure 2: Parity. 
Most of the acceptors were multiparous 117 (70.1\%). Several studies had similar finding. ${ }^{8,9}$ Primipara woman are less $50(29.9 \%)$. Primipara woman might be less inclined to accept $\mathrm{Cu}-\mathrm{T}$ for contraception. So, there is scope for increasing awareness among the primigravida woman and to motivate them for accepting $\mathrm{Cu}-\mathrm{T}$. Woman with parity two or three was $101(60.5 \%)$ and woman with parity more than three was very few $16(9.6 \%)$ This might be due to preference for permanent method by woman of higher order parity.

The number of woman who had their last childbirth more than two years back was $71(42.5 \%)$. This finding shows that a significant number of acceptors had long gap from last childbirth to acceptance of $\mathrm{Cu}-\mathrm{T}$. Some studies have found most of the acx 'ceptor used $\mathrm{Cu}-\mathrm{T}$ within less than 2 years of last childbirth. ${ }^{7}$

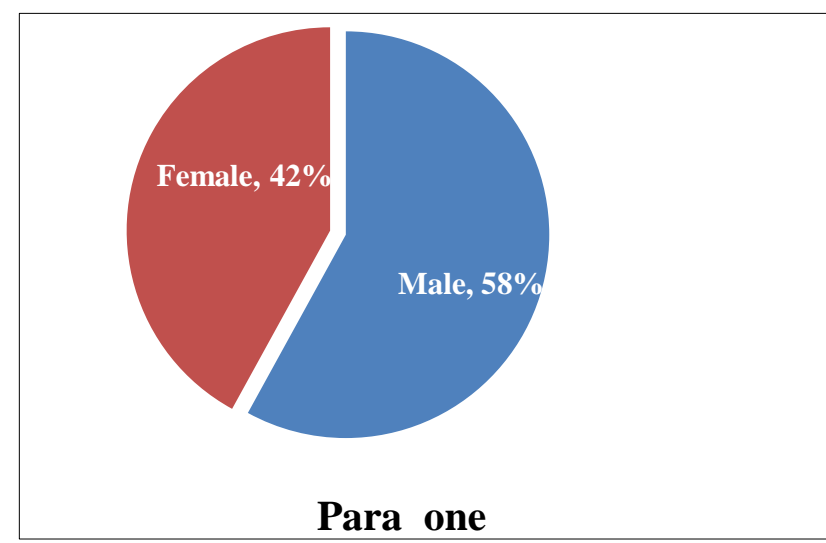

Figure 3: Primipara with only male /female child.

The number of woman with parity one with male child accepting $\mathrm{Cu}-\mathrm{T}$ is higher $29(58 \%)$ than that of with female child $21(42 \%)$. Similarly, woman with para two having two male child is higher $13(56.5 \%)$ than that of woman with parity two having only two female child $(43.48 \%){ }^{10}$ This might be due to preference for male child. Samel, Malhi P, Channon and Hamed reported similar finding. ${ }^{7,10-12}$

\section{CONCLUSION}

The present study has shown that there is a long interval of more than two years from last child birth to acceptance of $\mathrm{Cu}-\mathrm{T}$ in the majority of the woman. They had unwanted pregnancy during this period due to inconsistent use or total lack of use of effective contraceptive. So, there is a scope of improvement in the family planning activities so that these gaps could be filled up and thereby avoid abortion related mortality and morbidity. Some of the finding suggests that gender of children had influenced the timing as well as use of $\mathrm{Cu}-\mathrm{T}$.
This aspect needs more extensive study to substantiate our finding and to devise strategies to deal with the problem.

Funding: No funding sources

Conflict of interest: None declared

Ethical approval: The study was approved by the Institutional Ethics Committee

\section{REFERENCES}

1. United Nations, World Population Prospects, 2017 Revision, Available at: https:// www.un.org/ development/desa/publications/world-populationprospects-the-2017-revision.html.

2. A strategic approach to reproductive, maternal, newborn, child and adolescent health in India (RMNCH+A). Available at http://164.100.154.238/ images/pdf/RMNCH+A/ RMNCH+A_Strategy.pdf.

3. World Health Organization Report of a WHO technical consultation on birth spacing, 2005. Available at: https://www.who.int/maternal__ child_adolescent /documents/birth_spacing05/en/.

4. Okusanya BO, Oduwole O, Effa EE. Immediate postabortal insertion of intrauterine devices. Cochrane Database Syst Rev. 2014;7:CD001777.

5. Biswas R, Nandy S, Mitra K, Mandal PK, Ray S, Biswas AB. Profile of IUD acceptors attending postpartum unit of a teaching hospital. Indian $\mathrm{J}$ Comm Med. 2002;27(3):130.

6. Chandra S. A study of copper T acceptors. The J Family Welfare. 1996;42(2):55-7.

7. Samel DR, Senapati JN, Paradkar GV. Sociodemographic profile of copper- $T$ beneficiaries in the family planning out-patient department of a teaching hospital: a record-based descriptive study. Int J Res Med Sci. 2016;4(9):4067-71.

8. Abasiattai AM, Bassey EA, Udoma EJ. Profile of intrauterine contraceptive device acceptors at the university of oyu teaching hospital, Uyo, Nigeria. Ann Afr Med. 2008;7(1):1-5.

9. Bedi PK. A prospective study to assess the safety and expulsion rate of copper T380A in immediate postpartum period during caesarean section, Int J Reprod Contracept Obstet Gynecol. 2016;5(9):3195-9.

10. Malhi P, Singh S. Son preference and reproductive behaviour in rural Punjab. Guru Nanak J Sociol. 1995;16(2):31-40.

11. Channon MD. Son preference, parity progression and contraceptive use in South Asia, population. Horizons. 2015;12(1):24-36.

12. Hameed W, Azmat SK. Women's empowerment and contraceptive use: the role of independent versus couples' decision-making, from a lower middle income country perspective. PLoS One. 2014;9(8):e104633.

Cite this article as: Shyam $\mathrm{P}$, Ronghangpi $\mathrm{M}$, Rongphar RC. The socio-demographic profile of the acceptor of copper intrauterine device after medical termination of pregnancy in a tertiary care centre. Int J Reprod Contracept Obstet Gynecol 2019;8:4230-2. 